\title{
Penerapan Analisis CVP Sebagai Alat Perencanaan Laba UD Sukma Jaya: Efektif atau Semu?
}

\author{
Dian Hafiza Triana, Nidya Vitriana, Linda Hetri Suriyanti \\ Fakultas Ekonomi dan Bisnis, Universitas Muhammadiyah Riau, Pekanbaru, Indonesia \\ Email: dianhafizatrian@gmail.com,
}

\section{A R T I C L E I N F O}

Article History:

Received: 23 April 2020

Accepted: 01 Mei 2020

Available online:16 Mei 2020

Keywords:

Perencanaan Laba,

Cost Volume Profit

\section{A B S T R A C T}

\begin{abstract}
Manajemen yang baik menggunakan analisis yang terbukti efektif dan efisien seperti analisis cost-volume-profit (CVP). Penelitian ini bertujuan untuk membuktikan keefektivitasan analisis CVP dalam perencanaan laba dengan menentukan titik impas, margin kontribusi, dan margin of safety dari UD Sukma Jaya dengan pemisahan biaya variabel dan biaya tetap. Metode deskriptif dengan pendekatan studi kasus digunakan untuk menjawab pertanyaan penelitian (RQ) yaitu apakah analisis CVP efektif atau semu dalam mempengaruhi keptusan peningkatan laba perusahaan?. Jenis data yang digunakan adalah data kuantitatif yang menggunakan sumber data sekunder. Hasil penelitian yang dilakukan pada tahun 2019 diperoleh titik impas UD Sukma Jaya sebanyak 3.125 unit dengan titik impas penjualan sebesar Rp.6.249.638,3. Margin kontribusi pada tahun 2019 sebesar Rp.21.026.000 dengan rasio sebesar 86.4\%. Margin of safety dari susu kedelai sebesar 74,3\%. Untuk mencapai peningkatan keuntungan sebesar 35\% di tahun 2020, UD Sukma Jaya harus melakukan penjualan susu kedelai sebanyak 2.536 unit dengan harga jual Rp.2.500.
\end{abstract}

\section{Pendahuluan}

Perencanaan merupakan suatu usaha merumuskan tujuan, penyusunan program operasional secara detail dan penentuan strategi yang disusun untuk jangka waktu yang panjang dan jangka pendek untuk mencapai suatu tujuan tertentu (Dunia et al., 2012). Perencanaan yang baik sangat penting dilakukan sebagai bentuk komitmen terhadap perusahaan. Perencanaan juga memiliki peran dalam keberhasilan mengenai masa depan perusahaan untuk mencapai tujuan perusahaan khususnya perencanaan penjualan dan perencanaan laba. Penjualan berfokus pada berapa unit dan total penjualan yang dapat diraih oleh perusahaan sedangkan perencanaan laba adalah langkahlangkah yang ditempuh yang digunakan untuk mengevaluasi manajemen untuk mengukur optimalisasi dalam menciptakan laba perusahaan (Assa, 2013).

Analisis cost-volume-profit (BiayaVolume-Laba) memperkirakan bagimana perubahan biaya (baik biaya variable maupun biaya tetap), volume penjualan, dan harga mempengaruhi laba Perusahaan (Mowen et al., 2017). Analisis cost-volume-proFit ini digunakan untuk memprediksi volume penjualan yang akan mempengaruhi laba perusahaan sehingga dapat dijadikan alat perencanaan bagi manajerial untuk mengevaluasi volume penjualan yang dapat berubah karena perubahan harga, biaya variable dan biaya tetap. Analisis ini membantu manajer dalam memeriksa dampak yang mungkin terjadi 
karena keputusan strategis. Pengambilan keputusan yang dimaksud adalah seperti penentapan harga pokok produk, persetujuan atau penolakan atas job order dan titik impas untuk produk yang diperkirakan menguntungkan perusahaan.

Titik impas (break even point) adalah titik dimana total pendapatan sama dengan total biaya, yaitu titik saat laba sama dengan nol (Mowen et al., 2017). Dalam mencapai titik impas ada berbagai cara yang dapat digunakan salah satunya adalah menggunakan laba operasi dalam analisis cost-volume-profit. Analisis ini terbukti efektif dalam menjelaskan kepada manajer tentang berapa unit produk yang harus terjual atau berapa penjualan yang harus didapatkan agar menutupi seluruh biaya produksi. Seluruh unit yang terjual diatas titik impas akan menghasilkan laba. Tanpa analisa titik impas atau BEP ini, besar kemungkinan perusahaan akan gagal dalam menargetkan laba perusahaannya. Karena perusahaan tidak dapat melihat berapa batas produk yang wajib dijual untuk mencapai target laba.

Semua perusahaan dalam segala ukuran skala juga harus dapat menerapkan analisis yang tepat berkaitan dengan perencanaan penjualan dan perencanaan laba, tak terkecuali UD Sukma Jaya yang merupakan usaha rumahan dalam memproduksi susu kedelai dalam berbagai variant rasa diantaranya original, strawberry, coklat dan pandan. Dalam upaya pengembangan usahanya, Sukma Jaya terus melakukan pembenahan diri termasuk bersaing dipasaran dan menonjolkan kuantitas dan harga jual produknya. Berdasarkan data yang diambil dengan metode wawancara menunjukkan fluktuasi laba penjualan susu kedelai setiap bulannya. Namun, kadang kala akibat perencanaan yang kurang baik, Sukma Jaya sering mengalami salah target penjualan yang berujung tidak mencapai titik impas dan berakibat tidak mencapai laba kemudian merugi.

Oleh karena itu, penelitian ini dilakukan untuk menginvestigasi apakah analisis CVP efektif atau semu untuk perencanaan laba. Penelitian ini dilakukan dengan metode studi kasus pada UD Sukma Jaya. Dan diharapkan memberikan kontribusi praktis maupun teoritis dalam perencanaan laba bagi kalangan yang menggunakan analisis cost-volume-profit dalam memaksimalkan laba perusahaannya.

\section{Tinjauan Literatur}

\subsection{Perencanaan Laba}

Perencanaan laba merupakan aspek penting dalam perusahaan. Nilai suatu perusahaan dapat dikatakan bagus apabila memperoleh laba yang besar. Perencanaan laba merupakan rencana kerja yang telah diperhitungkan dengan cermat dimana implikasi keuangannya dinyatakan dalam bentuk proyeksi perhitungan rugi-laba, neraca, kas dan modal kerja untuk jangka panjang dan jangka pendek (Harahap, 2011). Sehingga perencanaan yang baik akan membuat perusahaan terus berkembang dan akan menghasilkan laba yang signifikan.

Dalam proses perencanaan laba jangka pendek perusahaan harus mengetahui informasi mengenai akuntansi diferensial untuk mempertimbangkan dampak biaya, volume penjualan dan harga jual terhadap laba perusahaan. Analisis titik impas dan analisis cost-volume-proft merupakan alat yang dapat membantu manajerial perusahaan dalam perencanaan laba jangka pendek.

\subsection{Perilaku Biaya}

Perilaku biaya (cost behavior) adalah istilah umum untuk mendeskripsikan apakah suatu biaya berubah saat tingkat output berubah (Mowen et al., 2017). Sedangkan menurut (Riwayadi, 2016), perilaku biaya mengkaji bagaimana total biaya dan biaya per unit berubah sehubungan dengan perubahan output (tingkat) driver aktivitas. Pemahaman terhadap perilaku biaya adalah kunci beberapa pembuatan keputusan organisasi. Manajer yang mengetahui perilaku biaya akan mampu memprediksi dengan lebih baik, apakah yang terjadi pada biaya dalam berbagai kondisi menurut (Winarko \& Astuti, 2018).

Tiga klasifikasi yang paling umum dari perilaku biaya adalah biaya tetap, biaya variabel, dan biaya semivariabel (Riwayadi, 2016). Biaya Tetap (fixed cost) adalah biaya yang jumlahnya tetap dalam batas relavan tertentu tanpa dipengaruhi oleh perubahan output driver aktivitas, sedangkan biaya per unitnya berubah berbanding terbalik dengan perubahan output driver aktivitasnya. Biaya Variabel (Variable Cost) adalah biaya yang 
totalnya berubah secara proposional dengan perubahan output driver aktivitas, sedangkan biaya per unitnya tetap dalam batas relavan tertentu. Batas relavan adalah batas di mana biaya per unit tersebut tidak berubah. Biaya Semivariabel (Semivariable Cost) adalah biaya yang totalnya berubah, tetapi tidak proposional dengan perubahan output driver aktivitas dan perubahan biaya per unit juga berbanding terbalik terbalik dengan perubahan output driver aktivitas.

Pemisahan unsur-unsur biaya tetap dan biaya variabel dari biaya semivariabel dapat dilakukan dengan menggunakan tiga cara yaitu Metode High-Low, metode scattergrapgh dan Metode least Square (Mowen et al., 2017). Metode high-low adalah metode yang memisahkan biaya campuran menjadi komponen biaya tetap dan biaya variable hanya dengan menggunakan titik data yang tertinggi dan terendah. Sedangkan metode scattergraph (diagram pencar) adalah suatu cara yang dapat digunakan untuk mengetahui hubungan biaya, dengan menggambarkan titik-titik data pada sebuah grafik. Terakhir, metode least square (kuadrat terkecil) yaitu cara statistika untuk menemukan garis regresi yang paling tepat melalui sekumpulan titik data.

\subsection{Analisis Cost-Volume-Profit (CVP)}

Analisis biaya volume laba merupakan teknik untuk menghitung dampak perubahan harga jual, volume penjualan, dan biaya terhadap laba, untuk membantu manajemen dalam perencanaan laba jangka pendek (Mulyadi, 2010). Cost-volume-profit (CVP) adalah alat yang sangat baik untuk perencanaan dan pengambilan keputusan. Bahkan costvolume-profit merupakan alat yang paling adaptif dan paling strategis penerapannya untuk digunakan oleh akuntan manajerial sebagai alat bantu para manajer dalam mengambil keputusan yang tepat bagi perusahaan seperti titik impas atau break even point (BEP).

Terdapat dua acara menghitung titik impas atau break even point menggunakan metode persamaan (Mowen et al., 2017), yaitu:

- Pendekatan laba operasi

Pendekatan persamaan operasi memfokuskan pada laporan laba-rugi sebagai alat yang berguna dalam mengorganisasikan biaya perusahaan dalam kategori biaya tetap dan variabel. Laporan tersebut dinamakan laporan laba rugi margin kontribusi (contribution margin income statement). Secara naratif dapat dituliskan sebagai berikut :

Laba Operasi $=(\mathrm{P}-\mathrm{V})-\mathrm{F}$

Keterangan:

$\mathrm{P}=$ Penjualan

$\mathrm{V}=$ Biaya variable

$\mathrm{F}=$ Biaya tetap

- Pendekatan margin kontribusi

Margin kontribusi adalah pendapatan penjualan dikurangi biaya variabel total. Pada titik impas, jumlah margin kontribusi setara dengan beban tetap (Winarko \& Astuti, 2018). Dirumuskan sebagai berikut:

a. Titik impas per unit

Menjelaskan kepada manajer mengenai besarnya unit yang harus terjual untuk menutupi semua biaya. Setiap unit yang terjual di atas titik impas akan menghasilkan laba.

$$
\text { Titik Impas ( Unit })=\frac{F}{p-V u}
$$

\section{b. Titik impas dalam nilai penjualan}

Mempermudah para manajer untuk melihat secara langsung seberapa dekat perusahaan sampai ke titik impas bahkan hanya dengan menggunakan data pendapatan penjualan

$$
\text { Titik Impas ( Rupiah })=\frac{F}{1-\frac{V}{P}}
$$

Keterangan:

$1-\frac{V}{p}=$ Rasio margin kontribusi

\subsection{Rasio Margin Kontribusi}

Rasio margin kontribusi (contribution margion ratio) adalah proporsi dari setiap penjualan dalam dolar yang tersedia untuk menutupi biaya tetap dan memberikan laba (Mowen et al., 2017).

Rasio Margin Kontribusi $=\frac{T M C}{p}$

atau

Rasio Margin Kontribusi $=\frac{M C}{C}$

Keterangan:

TMC = Total margin kontribusi

$\mathrm{P} \quad=$ Penjualan

MC = Margin kontribusi per unit

$\mathrm{C}=$ Harga jual 


\subsection{Margin of Safety (Titik Aman)}

Margin of safety adalah jumlah unit yang terjual atau pendapatan yang diperoleh di atas volume titik impas (Mowen et al., 2017). Dirumuskan sebagai berikut :

Margin of Safety = Penjualan - Titik Impas

atau dapat dinyatakan dalam persentase Rasio Margion of Safety $=\frac{\text { MOS }}{p} \times 100 \%$

Keterangan:

MOS = Margin of Safety

$\mathrm{P} \quad=$ Penjualan

\subsection{Degree Operating Leverage}

Operating leverage adalah penggunaan biaya tetap untuk meningkatkan perubahan dalam tingkat laba yang lebih tinggi saat aktivitas penjualan berubah (Mowen et al., 2017). Degree of operating leverage (DOL) dapat diukur untuk tingkat penjualan yang ada dengan menggunakan rasio margin kontribusi terhadap laba operasi. Semakin besar degree of operating leverage, semakin vesar perubahan dalam penjualan akan mempengaruhi laba operasi. Dirumuskan sebagai berikut :

$$
\mathrm{DOL}=\frac{\text { Total Margin Kontribusi }}{\text { Laba } O_{\text {perasi }}}
$$

\subsection{Kerangka Penelitian}

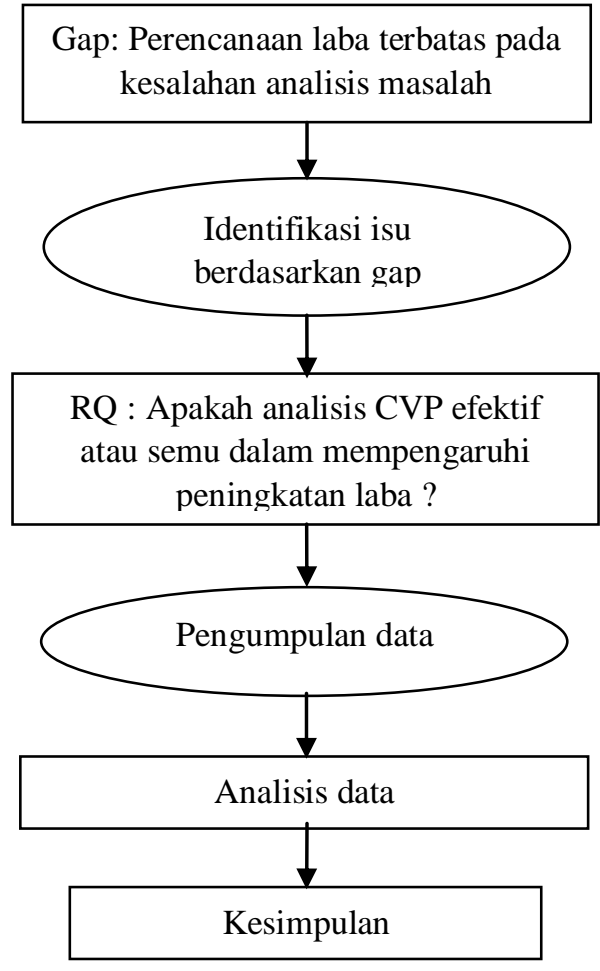

Gambar 1. Kerangka Penelitian
Berdasarkan kerangka penelitian, terdapat gap yaitu perencanaan laba yang terkendala akibat kesalahan analisis sehingga dibutuhkan analisis yang tepat guna mempengaruhi peningkatan laba. Kemudian peneliti mengidentifikasi isu penelitian berdasarkan gap yang terjadi. Sehingga timbul pertanyaan apakah analisis CVP efektif atau semu dalam mempengaruhi peningkatan laba. Sehingga Peneliti mengumpulkan data kuantitatif dan menganalisa data tersebut sehingga kemudian diharapkan mendapatkan kesimpulan. Oleh karena itu, pertanyaan penelitian (research question/RQ) ini adalah sebagai berikut:

RQ: Apakah analisis margin kontribusi, titik impas, margin of safety, operating leverage efektif atau semu dalam membantu para manajerial dalam mengambil keputusan dan meningkatkan laba perusahaan?

\subsection{Penelitian Terdahulu}

Iswara \& Susanti (2017) mengungkapkan bahwa suatu perusahaan membutuhkan perencanaan untuk membantu manajemen dalam penaksiran tingkat laba yang ingin diperoleh, dengan analisis Cost-Volume-Profit yang berfokus pada berbagai faktor yang mempengaruhi perubahan dalam komponen laba. Penelitian ini bertujuan untuk mengetahui penerapan analisis CVP sebagai dasar perencanaan laba yang diharapkan untuk tahun 2017. Metode yang digunakan adalah metode deskriptif dengan pendekatan studi kasus. Peneliti mengumpulkan informasi perusahaan kemudian melakukan analisis data. Analisis CVP dilakukan dengan analisis break event point (BEP), contribution margin, dan margin of safety. Hasil penelitian menunjukkan di tahun 2016 margin kontribusi sebesar Rp 144.070.100. Penjualan minimum sebesar Rp140.695.100 dan titik impas Rp 84.375.000. Perusahaan menetapkan laba sebesar $22 \%$ dari tahun sebelumnya. Untuk mencapai laba yang diharapkan, penjualan ditargetkan sebesar Rp 256.071.100 pada tahun 2017. Manajemen dapat menerapkan analisis CVP untuk membantu dalammerencanakan laba di tahun mendatang. 


\section{Metode Penelitian}

Penelitian ini digunakan metode studi kasus. Desain studi kasus adalah suatu penelitian yang dilakukan secara intensif terinci dan mendalam terhadap suatu prganisasi, lembaga dan gejala tertentu. Ditinjau dari wilayahnya, maka penelitian kasus hanya meliputi daerah atau subjek yang sangat sempit (Sugiyono, 2013). Penelitian ini bersifat deskriptif dengan jenis data kuantitatif dan sumber data sekunder yang didapat dari dokumentasi berupa laporan penjualan tahun 2019.

Objek penelitian adalah UD Sukma jaya dan informan penelitian adalah pemilik UD Sukma Jaya yaitu Ibu Sukmawati Nadir. Instrumen yang digunakan dalam penelitian adalah panduan wawancara yang berupa pertanyaan yang ditanyakan kepada informan mengenai harga per satuan produk yang diproduksi, berapa banyak produk yang dijual perbulan dan berapa laba perbulannya. Lokasi Penelitian berada di jalan Muhajirin Perumahan Griya Mas Blok D20.

Teknis analisa data menggunakan interavtive model analysis dari Miles \& Huberman (1994) yang menerapkan langkahlangkah penelitian mulai dari pengumpulan data (data collection), reduksi data (data reduction), penyajian data (data display) dan penarikan kesimpulan atau verifikasi (conclutions).

- Penyajian Data

Pengumpulan data dilakukan pertama kali guna mendapatkan bahan penelitian yang berupa hasil wawancara, hasil observasi maupun dokumentasi yang digunakan dalam penelitian seperti laporan penjualan.

- Reduksi Data

Reduksi data adalah suatu bentuk analisis yang menajamkan, menggolongkan, mengarahkan, membuang data yang tidak perlu dan mengorganisasi data dengan cara sedemikian rupa sehingga simpulan final dapat ditarik dan diverifikasi (Miles \& Huberman, 1994). sehingga didapatkan data yang diperlukan peneliti adalah laporan penjualan tahun 2019.

\section{- Penyajian Data}

Data disajikan lebih baik dalam model yang valid. seperti bagan, grafik ataupun gambar yang dirancang agar mudah dipahami dan peneliti dapat menganalisa serta mengambil keputusan untuk langkah selanjutnya.

- Penarikan Kesimpulan atau Verifikasi

Penarikan kesimpulan hanyalah sebagian dari suatu kegiatan konfigurasi yang utuh menurut (Miles \& Huberman, 1994). Penarikan kesimpulan merupakan langkah terakhir dari suatu metode penelitian. Hal ini berarti peneliti sudah mencapai akhir dari penelitiannya. Kesimpulan akhir harus diverifikasi dan teruji kebenarannya serta kesimpulan tersebut dapat dipertanggungjawabkan.

Berikut skema model analisis data interaktif oleh Miles \& Huberman (1994):

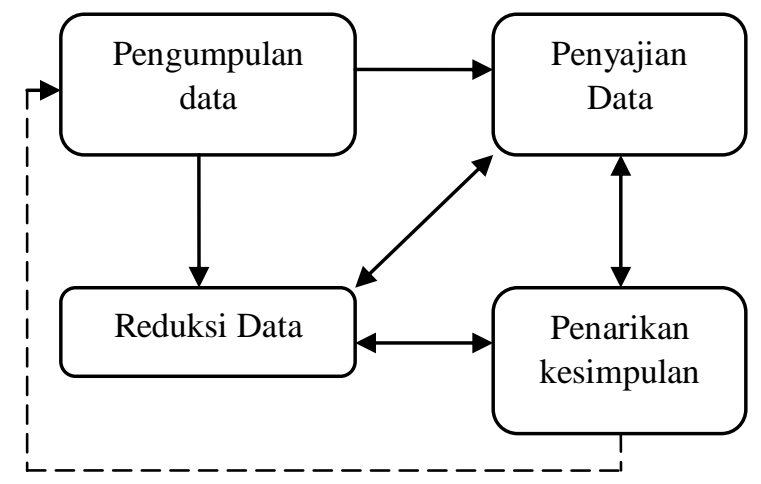

Gambar 2. Model Analisis Data Interaktif Miles dan Huberman (1994)

Metode analisis data perencanaan laba menggunakan data kuantitatif yaitu analisis cost-volume-profit (CVP) dengan menghitung margin contribution, Rasio Margin kontribusi, break evenpoint, margin of safety, Rasio margin of safety, Operating leverage dan terakhir menyusun perencanaan laba tahun yang akan datang dengan mendasarkan pada target yang direncanakan.

\section{Hasil Penelitian dan Pembahasan}

\subsection{Gambaran umum perusahaan}

UD Sukma Jaya adalah industri yang bergerak dibidang pembuatan susu kedelai dan didirikan oleh ibu Sukmawati Nadir sejak tahun 2009 yang berlokasi di Jalan Muhajirin Perumahan Purna Griya Mas Blok D19, Kecamatan Tampan, Kota Pekanbaru, Riau. Lokasi yang strategis terletak di daerah perumahan ini membuat Sukma Jaya bisa meraup keuntungan yang lebih besar. Meski demikian, dibutuhkan manajemen yang baik agar usaha rumahan tersebut dapat bertahan untuk waktu yang cukup lama. UD Sukma Jaya memiliki biaya tetap yaitu biaya tenaga kerja, 
serta biaya variabel yaitu biaya bahan baku, biaya air, dan biaya gas.

\subsection{Data pendapatan penjualan}

UD Sukma Jaya memproduksi berupa prosuk susu kedelai empat varian rasa, berikut adalah penjualan biaya tetap dan biaya variabel UD Sukma Jaya tahun 2019. Informasi mengenai penjualan UD Sukma Jaya selama tahun 2019 ditampilkan pada table 1. Berdasarkan tabel tersebut, jumlah penjualan mengalami fluktuasi atau tidak tetap perbulannya. Penjualan tertinggi ada pada bulan Februari sebesar Rp 2.650.000 dan penjualan terendah ada di bulan Oktober sebesar Rp1.400.000.

Tabel 1. Data Penjualan tahun 2019

\begin{tabular}{cc}
\hline Bulan & Penjualan \\
\hline Januari & 2.512 .000 \\
Februari & 2.650 .000 \\
Maret & 2.240 .000 \\
April & 1.912 .000 \\
Mei & 1.706 .000 \\
Juni & 1.846 .000 \\
Juli & 2.003 .000 \\
Agustus & 1.792 .000 \\
September & 2.050 .000 \\
Oktober & 1.400 .000 \\
November & 2.270 .000 \\
Desember & 1.953 .000 \\
\hline Total Penjualan & 24.334 .000
\end{tabular}

Sumber : UD Sukma Jaya,2019

Tabel 2 berikut merupakan rincian biaya variabel UD Sukma Jaya perbulan yang meliputi biaya bahan baku, biaya air dan biaya gas.

Tabel 2. Data Biaya Variabel Perbulan

\begin{tabular}{cccc}
\hline Bulan & $\begin{array}{c}\text { Biaya Bahan } \\
\text { Baku (Rp) }\end{array}$ & $\begin{array}{c}\text { Biaya air } \\
(\mathrm{Rp})\end{array}$ & $\begin{array}{c}\text { Biaya } \\
\text { Gas (Rp) }\end{array}$ \\
\hline Januari & 261.000 & 35.000 & 30.000 \\
Februari & 270.000 & 40.000 & 36.000 \\
Maret & 243.000 & 30.000 & 30.000 \\
April & 216.000 & 30.000 & 28.000 \\
Mei & 195.000 & 25.000 & 28.000 \\
Juni & 200.000 & 28.000 & 30.000 \\
Juli & 216.000 & 32.000 & 32.000 \\
Agustus & 195.000 & 25.000 & 25.000 \\
September & 200.000 & 30.000 & 32.000 \\
Oktober & 150.000 & 17.000 & 18.000 \\
November & 245.000 & 30.000 & 30.000 \\
Desember & 216.000 & 32.000 & 28.000 \\
\hline Total Biaya Variabel & 2.607 .000 & 355.000 & 327.000 \\
\hline
\end{tabular}

Sumber : UD Sukma Jaya,2019
Tabel 3. Data Biaya Variabel tahun 2019

\begin{tabular}{cc}
\hline Bulan & Total Biaya Variabel (Rp) \\
\hline Januari & 326.000 \\
Februari & 346.000 \\
Maret & 303.000 \\
April & 274.000 \\
Mei & 248.000 \\
Juni & 258.000 \\
Juli & 280.000 \\
Agustus & 245.000 \\
September & 262.000 \\
Oktober & 185.000 \\
November & 305.000 \\
Desember & 276.000 \\
\hline Total Biaya Variabel & 3.308 .000 \\
\hline
\end{tabular}

Tabel 3 merupakan total keseluruhan biaya variable UD Sukma Jaya untuk memproduksi susu kedelai selama tahun 2019 adalah Rp 3.308.000.

Tabel 4. Data Biaya Tetap tahun 2019

\begin{tabular}{cc}
\hline Bulan & Total Biaya Tetap (Rp) \\
\hline Januari & 450.000 \\
Februari & 450.000 \\
Maret & 450.000 \\
April & 450.000 \\
Mei & 450.000 \\
Juni & 450.000 \\
Juli & 450.000 \\
Agustus & 450.000 \\
September & 450.000 \\
Oktober & 450.000 \\
November & 450.000 \\
Desember & 450.000 \\
\hline Total Biaya Variabel & 5.400 .000
\end{tabular}

Tabel 4 merupakan biaya tetap UD Sukma Jaya untuk memproduksi susu kedelai selama tahun 2019 sebesar Rp 5.400.000.

Tabel 5. Data Perolehan Laba 2019 (dalam ribuan rupiah)

\begin{tabular}{ccccc}
\hline Bulan & $\begin{array}{c}\text { Penjualan } \\
(\mathrm{Rp})\end{array}$ & $\begin{array}{c}\text { Total } \\
\text { biaya }\end{array}$ & Laba & $\begin{array}{c}\text { Perolehan } \\
\text { laba }\end{array}$ \\
\hline Januari & 2.512 & 776 & 1.736 & 0.109 \\
Februari & 2.650 & 796 & 1.854 & 0.117 \\
Maret & 2.240 & 577 & 1.663 & 0.105 \\
April & 1.912 & 724 & 1.188 & 0.075 \\
Mei & 1.706 & 698 & 1.008 & 0.063 \\
Juni & 1.846 & 708 & 1.138 & 0.072 \\
Juli & 2.003 & 730 & 1.273 & 0.080 \\
Agustus & 1.792 & 695 & 1.097 & 0.069 \\
September & 2.050 & 712 & 1.338 & 0.084 \\
Oktober & 1.400 & 635 & 765 & 0.048 \\
November & 2.270 & 755 & 1.515 & 0.095 \\
Desember & 1.953 & 726 & 1.227 & 0.077 \\
\hline & 24.334 & 8.532 & 15.802 & \\
\hline
\end{tabular}

Sumber: UD Sukma Jaya, 2019 
Tabel 5 di atas memperlihatkan data laba yang dihasilkan oleh UD Sukma Jaya selama tahun 2019. Laba yang dihasilkan sebesar Rp 15.801.000.

\subsection{Analisis cost-volume-profit pada UD Sukma Jaya}

Analisis cost-volume-profit adalah suatu metode analisis untuk melihat hubungan antara besarnya biaya yang dikeluarkan suatu perusahaan dan besarnya volume penjualan serta laba yang diperoleh pada suatu periode tertentu (Palawiten, 2014). Dasar-dasar analisis cost-volume-profit yang akan dibahas merupakan rangkaian analisis yang akan menjelaskan hubungan antara biaya, volume, dan, laba.

\section{- Hasil Analisis Margin Kontribusi}

Margin kontribusi didapatkan dari hasil pengurangan penjualan dengan total biaya variabel.

\begin{tabular}{lcc}
\hline & Total & Per unit \\
\hline Penjualan & & \\
$2000 \times 12.167$ & 24.334 .000 & 2000 \\
Biaya Variabel & & \\
$271,9 \times 12.167$ & $\underline{(3.308 .000)}$ & $\underline{(271,9)}$ \\
Margin kontribusi & $\underline{21.026 .000}$ & 1728.1 \\
Biaya Tetap & $\underline{(5.400 .000)}$ & \\
Laba Bersih & 15.526 .000 & \\
\hline
\end{tabular}

$$
\begin{aligned}
\text { Rasio Margin kontribusi } & =\frac{1728.1}{2.000} \\
& =0,864 \\
& =86.4 \%
\end{aligned}
$$

Margin kontribusi tahun 2019 adalah sebesar Rp 21.026.000 atau sebesar 1728.1 per unit. Sedangkan rasio margin kontribusi adalah $86.4 \%$.

\section{- Hasil Analisis Titik Impas (BEP)}

Titik impas dalam unit dapat dihitung sebagai berikut :

$$
\begin{gathered}
=\frac{\text { Biaya Tetap }}{\text { Harga Jual-Biaya variabel per unit }} \\
=\quad \frac{5.400 .000}{2000-271,9} \\
=\quad 3.125 \text { unit }
\end{gathered}
$$

Titik impas dalam rupiah dapat dihitung sebagai berikut :

$$
\begin{gathered}
=\frac{\text { Biaya Tetap }}{1-\frac{\text { BiayaVariabe perunit }}{\text { Harga jual perunit }}} \\
=\frac{5.400 .000}{1-\frac{271_{s} 9}{2.000}} \\
=\frac{5.400 .000}{0,86405} \\
=\text { Rp. } 6.249 .638,3
\end{gathered}
$$

Titik impas UD Sukma Jaya yang tercapai tahun 2019 adalah sebanyak 3.125 unit dan total penjualan sebanyak Rp 6.249.638,3 dan pada saat penjualan tersebut perusahaan memperoleh laba, karena laba bersih yang didapat pada tahun tersebut mencapai Rp 15.526.000.

- Analisis Margin of Safety (MOS)

$$
\begin{aligned}
\mathrm{MOS} & =\text { Penjualan }- \text { Titik Impas } \\
& =24.334 .000-6.249 .638,3 \\
& =18.094 .361,7
\end{aligned}
$$

Dengan rasio margin of safety sebagai berikut :

$$
\begin{aligned}
& =\frac{18 \cdot 094 \cdot 361_{x} 7}{24 \cdot 334.000} \\
& =0,743 \\
& =74,3 \%
\end{aligned}
$$

Dengan demikian, UD Sukma Jaya masih bisa mentolerir jika terjadi penurunan sebanyak 74,3\% atau Rp 18.094.361,7 hingga titik impas agar tidak mendapatkan kerugian.

- Analisis Degree of Operating Leverage (DOL)

$$
\begin{aligned}
\text { DOL } & =\frac{\text { Total Margin Kontribusi }}{\text { Laba Operasi }} \\
& =\frac{21.026 .000}{15.526 .000} \\
& =1.35
\end{aligned}
$$

\subsection{Perencanaan Laba Perusahaan}

Manajemen yang baik dapat membuat suatu perusahaan dikatakan berhasil apabila memenuhi target laba. Maka dari itu, pada tahun yang akan datang, UD Sukma Jaya menargetkan Penjualan naik sebesar 35\% sehingga menjadi Rp32.850.900. Biaya tetap dan biaya variable naik 5\% sehingga menjadi Rp3.473.400 dan Rp5.670.000 dan perkiraan kenaikan harga jual menjadi Rp2.500. Sehingga 
Analisis cost-volume-proftt UD Sukma Jaya untuk tahun depan adalah sebagai berikut:

\section{- Analisis Margin Kontribusi}

\begin{tabular}{lcc}
\hline & Total & Per unit \\
\hline Penjualan & & \\
$2500 \times 13.140$ & 32.850 .900 & 2500 \\
Biaya Variabel & & \\
264,3 $\times 13.140$ & $\underline{(3.473 .400)}$ & $\underline{(264,3)}$ \\
Margin kontribusi & 29.377 .500 & 2235,7 \\
Biaya Tetap & $\underline{(5.670 .000)}$ & \\
Laba Bersih & 23.707 .500 & \\
\hline
\end{tabular}

$$
\begin{aligned}
\text { Rasio Margin kontribusi } & =\frac{2235,7}{2.500} \\
& =0,894 \\
& =89,4 \%
\end{aligned}
$$

Target margin kontribusi tahun 2020 adalah sebesar Rp29.377.500 atau sebesar 2235,7 per unit. Sedangkan rasio margin kontribusi adalah $89,4 \%$.

- $\quad$ Analisis Titik Impas (BEP)

Target titik impas dalam unit dapat dihitung sebagai berikut :

$$
\begin{aligned}
& =\frac{\text { Biaya Tetap }}{\text { Harga Jual-Biaya variabel per unit }} \\
& =\frac{5.670 .000}{2500-264,3} \\
& =2.536 \text { unit }
\end{aligned}
$$

Titik impas dalam rupiah dapat dihitung sebagai berikut :

$$
\begin{aligned}
& =\frac{\text { Biaya Tetap }}{1-\frac{\text { BiayaVariabe perunit }}{\text { Harga jual perunit }}} \\
& =\frac{5.670 .000}{1-\frac{264.3}{2.500}} \\
& =\frac{5.670 .000}{0,89428} \\
& =R p 6.340 .296
\end{aligned}
$$

Target titik impas UD Sukma Jaya tahun 2020 yang akan datang adalah sebanyak 2.536 unit dan total penjualan sebanyak Rp6.340.296 dan pada saat penjualan tersebut perusahaan memperoleh laba. karena laba bersih yang didapat pada tahun tersebut mencapai Rp23.707.500.
- $\quad$ Analisis Margin of Safety

$$
\begin{aligned}
& =\text { Penjualan }- \text { Titik Impas } \\
& =32.850 .900-6.340 .296 \\
& =\operatorname{Rp} 26.510 .604
\end{aligned}
$$

Dengan rasio margin of safety sebagai berikut :

$$
\begin{aligned}
& =\frac{26.510 .604}{32.850 .900} \\
& =0,806=80,6 \%
\end{aligned}
$$

Artinya, UD Sukma Jaya masih bisa mentolerir jika terjadi penurunan sebanyak 80,6\% atau Rp26.510.604 hingga titik impas agar tidak mendapatkan kerugian.

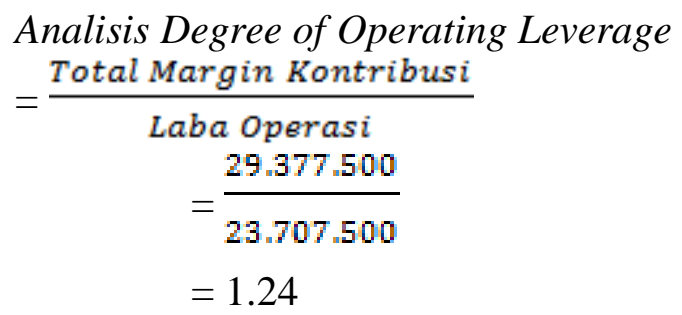

\subsection{Pembahasan}

Analisis cost-volume-profit sangat efektif, efisien, strategis dan adaptif jika digunakan oleh para manajerial untuk mengambil keputusan, implementasi pengekompokan biaya tetap dan biaya variable yang tujuannya untuk menaikkan laba perusahaan. Ada beberapa hal yang harus diperhatikan terkait menaikkan laba perusahaan, yaitu margin kontribusi, rasio margin kontribusi, titik impas dalam unit, titik impas dalam nilai penjualan, margin of safety, rasio margion of safety, dan degree of operating leverage. beberapa hal yang disebutkan itu sangat membantu manajerial dalam menentukan langkah untuk menjaga kestabilan perusahaan dalam meraih laba. Pada UD Sukma Jaya, ada beberapa bulan yang mengalami kerugian dikarenakan tidak sebandingnya pernjualan dengan biaya tetap dan biaya variable yang telah dikeluarkan. Perusahaan harus mempu mengestimasi berapa harga jual, biaya tetap dan biaya variable agar laba operasi yang didapatkan bisa maksimal. Titik impas dalam unit dan nilai penjualan dalam hal ini sangat penting untuk dihitung agar perusahaan dapat mengetahui limit dari penjualan agar tak mencapai kerugian. Untuk mencari taget laba dilakukan dengan pendekatan margin kontribusi dan laba operasi. Agar perusahaan mengetahui resiko penjualan, digunakan margin of safety sebagai analisis kasar berapa jumlah unit atau berapa rupiah pendapatan yang diperoleh di atas volume titik impas. 


\section{Kesimpulan}

Penelitian ini memberikan kesimpulan bahwa analisis CVP terbukti efektif menaikkan laba perusahaan dan berguna bagi manajemen dalam mengambil keputusan. Berbagai bidang industri perusahaan dapat menggunakan analisis CVP untuk menentukan titik impas yang berguna sebagai tolak ukur penjualan telah mencapai laba atau tidak. Untuk menerapkan analisis CVP, perusahaan harus menghitung Margin kontribusi dan rasionya, titik impas (break even point), titik aman (margin of safety), dan degree of operating leverage serta menganalisa perencanaan laba yang ditargetkan. Berdasarkan analisa yang dilakukan maka perusahaan akan bisa menghitung biaya, volume produk dan harga jual dan laba yang dicapai.

Hasil penelitian ini memberikan implikasi kepada manajemen UD Sukma Jaya dalam melakukan analisis cost-volume-profit (CVP) sehingga bisa digunakan dalam pengambilan keputusan perusahaan, misalnya terkait dengan penggunaan biaya variabel dan biaya tetap. Analisis CVP juga bisa digunakan untuk meningkatkan laba perusahaan. Selain itu, dengan analisis titik impas, manajemen juga mengetahui berapa unit produk yang harus terjual agar mencapai target laba yang diharapkan.

Penelitian ini memiliki keterbatasan yaitu terkait dengan perhitungan multi produk. UD Sukma Jaya memiliki empat variasi produk namun dijual dengan harga yang sama, sehingga peneliti tidak berkesempatan untuk menganalisis multi produk menggunakan analisis CVP, sehingga penelitian lanjutan diharapkan bisa lebih menjabarkan tentang multi produk tersebut.

\section{Daftar Pustaka}

Assa, R. (2013). Analisis Cost-Volume-Profit (Cvp) Dalam Pengambilan Keputusan Perencanaan Laba Pada PT. Tropica Cocoprima. Jurnal Riset Ekonomi, Manajemen, Bisnis Dan Akuntansi.

Dunia, Firdaus, \& Abdullah, W. (2012). Akuntansi Biaya (3rd ed.). Salemba Empat.

Harahap, S. S. (2011). Analisis Kritis Atas Laporan Keuangan. Grafindo Persada.

Iswara, U. S., \& Susanti. (2017). Analisis Cost Volume Profit Sebagai Dasar Perencanaan Laba Yang Diharapkan (Studi Pada Perusahaan Kopi Di Kabupaten Jember). Jurnal RAK (Riset Akuntansi Keuangan), 2(3), 67-76. https://doi.org/10.31002/rak.v4i1.1379.

Miles, M. ., \& Huberman, A. . (1994). Qualitative Data Analysis. Sage Publisher.

Mowen, M. M., Hansen, D. R., \& Heitger, D. L. (2017). Dasar-Dasar Akuntansi Manajerial (A. Sustiwi (ed.); 5th ed.). Salemba Empat.

Mulyadi. (2010). Akuntansi Biaya. STIE YPKPN.

Palawiten, A. (2014). Analisis Cost Volume Profit Untuk Perencanaan Laba Pada UD Gladys Bakery. EMBA, 2, 12. https://ejournal.unsrat.ac.id/index.php/emb a/article/download/5004/4522.

Riwayadi. (2016). Akuntansi Biaya (A. Sustiwi (ed.); 2nd ed.). Salemba Empat.

Sugiyono. (2013). Memahami Penelitian Kualitatif. ALFABETA.

Winarko, S. P., \& Astuti, P. (2018). Analisis Cost-Volume-Profit Sebagai Alat Bantu Perencanaan Laba (Multi Produk) Pada Perusahaan Pia Latief Kediri. Jurnal Nusantara Aplikasi Manajemen Bisnis, 3(2),9.https://doi.org/10.29407/nusamba.v3 i2.12143. 